Innlegg på inntil 400 ord lastes opp i http://mc.manuscriptcentral.com/tidsskriftet.

Redaksjonen forbeholder seg retten til å foreta redaksjonelle endringer.

Forfattere av vitenskapelige artikler har automatisk tilsvarsrett (jf. Vancouver-gruppens regler).

\section{Tidfesting av medisinhistoriske begivenheter}

I Tidsskriftet nr. $13-14 / 2010$ testet Skagen m.fl. medisinske historiekunnskaper hos studenter og leger (1). Som de antyder kan fasitsvarene for noen av hendelsene være diskutable, men for en av milepælene er fasiten i alle fall gal.

Nyretransplantasjon som gjennombrudd kan tidfestes forskjellig. I 1933 utførte Yurii Voronoy i Kherson, Ukraina den første menneske-til-menneske nyretransplantasjon (2). Nyren produserte urin i to døgn før den stoppet opp, og pasienten døde. Senere ble det gjort en rekke transplantasjonsforsøk rundt om i verden, men den første vellykkede fant sted i Boston i desember 1954. Begivenheten var såpass stor at den medførte en nobelpris til Murray og Merrill i 1990. Når akkurat denne transplantasjonen ble den første vellykkede i sitt slag, skyldtes det at giver var pasientens eneggede tvillingbror, slik at man unngikk all immunologiproblematikk.

Den første nyretransplantasjonen i Norden ble utført av Leif Efskind på Rikshospitalet i 1956. Pasienten levde med nyren i én måned, tross både $\mathrm{ABO}$-uforlikelighet og mangel på effektiv immunsuppresjon. Den første langtids vellykkede nyretransplantasjonen i Norge fant sted på Ullevål sykehus i 1963, og det kan synes som det er denne begivenheten Skagen, basert på Westin, har lagt til grunn for sin tidfesting. Som etablert behandling i Norge kan nyretransplantasjon tidfestes til 1969 , de tidligere må kunne kalles eksperimentell behandling.

Hva som skal være fasitsvar kan følgelig diskuteres, det avhenger av premissene man la frem for de spurte. Var det kun stikkordet «nyretransplantasjon», burde man, som nobelkomiteen, valgt 1954 . Norske nyresviktpasienter ville kanskje heller gå for 1969. Historikken har for øvrig vært korrekt gjengitt i Tidsskriftet flere ganger $(3,4)$. De som måtte ha husket årstall derfra fikk altså feil fra Skagen m.fl.

At dialysebehandling tidfestes til 1944, er forståelig. Det var da Willem Kolff første gang greide å få en pasient med akutt nyresvikt til å overleve til nyrefunksjonen tok seg opp igjen. Den første som prøvde å gi mennesker dialyse var Georg Haas i Giessen i 1923. Men dialyse ble aldri en langtidsmulighet før Belding Scribner i Seattle lanserte teflonsilikonshunten i 1960, så dette kunne like gjerne vært satt som gjennombruddsåret. Til Norge kom det første dialyseutstyret i drift i 1956 (på Rikshospitalet), etter at man hadde mistet sjansen til en vellykket tvillingtransplantasjon i 1955 fordi pasienten døde av sin nyresvikt før man kunne operere (5).

\section{Torbjørn Leivestad}

Immunologisk Institutt

Rikshospitalet

\section{Litteratur}

1. Skagen KM, Junker A, Nylenna M et al. Studenter og legers tidfesting av viktige medisinhistoriske begivenheter. Tidsskr Nor Legeforen 2010; 130: 1364-7.

2. Matevossian E et al. Surgeon Yurii Voronoy (1895-1961) - a pioneer in the history of clinical transplantation: in memoriam at the 75th anniversary of the first human kidney transplantation. Transplant Int 2009; 22: 1132-9.

3. Reisæter AV. Nyretransplantasjon i Noreg - eit historisk perspektiv. Tidsskr Nor Lægeforen 1999: 119: 3163-6.

4. Thorsby E. Norsk transplantasjonsmedisin gjennom 50 år. Tidsskr Nor Lægeforen 2006; 126 : 3305-10.

5. Cappelen C. Medisinsk teknikk. Tidsskr Nor Lægeforen 1974; 94: 827-33.

\section{Skagen og medarbeidere svarer:}

Vi takker Torbjørn Leivestad, og bøyer oss i full respekt for hans interessante redegjørelse for nyretransplantasjonens historie, både internasjonalt og $\mathrm{i}$ Norge. Han påpeker med dette en kjent svakhet ved datering av begivenheter som kjennetegnes av utvikling gjennom mange trinn, samtidig som han også bekrefter at vår artikkel tjener litt av sin tenkte hensikt. Våre «fasitsvar» kan som tidligere nevnt være diskutable, men en slik diskusjon kan bare ses på som konstruktiv og berikende. Vi kan dessuten berolige Leivestad og deltakerne i undersøkelsen med at avvikene fra «fasitsvarene» var såpass markante at selv denne årstallsjusteringen ikke ville ha endret på våre hovedkonklusjoner. Ja, vi har faktisk regnet om igjen.

Flere av angivelsene i den årstallstabellen deltakerne fikk forelagt, og som er gjengitt i artikkelens ramme 1 , er basert på arbeidet til den britiske legen og helsejournalisten James Le Fanu (1). Årstallet 1963 for nyretransplan- tasjon hører med til disse. Som Leivestad skriver, ble det i 1954 utført en vellykket transplantasjon mellom eneggede tvillinger, men det var i mange år tilnærmet umulig å komme rundt immunsystemets avstøtning. Først ved en konferanse i 1963 kunne amerikaneren Thomas Starzl presentere en lang rekke vellykkede transplantasjoner, der han kombinerte de kirurgiske teknikkene med steroidbehandling samt bruk av det den gang nye midlet azatioprin (1). Det er nærliggende å tro at dette var del av den kunnskapen norske kirurger fikk med seg via Richard E. Wilson fra Brigham Hospital (2); gruppen der Wilson arbeidet publiserte sine resultater med henvisning til Starzl i 1964 (3).

Det er naturligvis ikke dermed sagt at Le Fanus årstall er noe riktigere enn de årstallene Leivestad gir gode begrunnelser for. Men den tabellen vi laget på basis av Le Fanus bok, tror vi fortsatt gir en noenlunde riktig tidfesting av merkesteiner i den medisinske utvikling, med tidsangivelser som for mange fortsatt er ukjente, og av og til overraskende. Hvis flere av Tidsskriftets lesere har funnet grunn til å diskutere enkelte av årstallene, er mye av vår hensikt med artikkelen oppnådd. Så kan vi selvsagt diskutere om historiker og utenriksminister Halvdan Koht (1873-1965) hadde rett i sin påstand: "Årstala er det viktigaste i soga».

\section{Knut Mork Skagen \\ Asbjørn Junker \\ Magne Nylenna \\ Steinar Westin}

Institutt for samfunnsmedisin

Norges teknisk-naturvitenskapelige universitet

Litteratur

1. Le Fanu J. The rise and fall of modern medicine. London: Little Brown, 1999.

2. Thorsby E. Norsk transplantasjonsmedisin giennom 50 år. Tidsskr Nor Legeforen 2006; 126: 3305-10.

3. Murray JE, Merrill J P. Dammin GJ et al. Current evaluation of human kidney transplantation. Ann N Y Acad Sci 1964; 120: 545-57.

\section{Bløtdelsskader etter lavhastighetskollisjoner}

Schrader og medarbeidere bagatelliserer i Tidsskriftet nr. 5/2010 risikoen for kroniske nakkeplager etter trafikkulykker (1). Ifølge Quebec Task Force-rapporten fra 1995 (2) kan nakkeslangmekanisme føre til skade på en rekke strukturer i nakken. I en svensk rapport med bidrag fra relevante spe- 